\title{
The Correlation of Social Support and Self-Efficacy on Early Childhood Inclusive Teachers' Performances
}

\author{
Luh Ayu Tirtayani ${ }^{1 *}$, Nice Maylani Asril ${ }^{1}$ \\ ${ }^{1}$ Universitas Pendidikan Ganesha, Indonesia \\ "Corresponding author. Email: ayu.tirtayani@undiksha.ac.id
}

\begin{abstract}
This study aimed at finding out the correlation of social support and self-efficacy on performance among early childhood inclusive education teachers in Bali. Teachers as educators have an important role in implementing inclusion classes, especially in early childhood education (PAUD). The proffer of inclusive program implementation is closely related to teacher's performance. As an educator, teacher's belief of their ability to manage class and perception of social support become an important factor. This study focused on teacher's performance, self-efficacy, and social support. This study used quantitative approach and there were 170 teachers participated on the survey. The result showed that there was a significant correlation $(\alpha<.05)$ between social support and self-efficacy toward teacher's performance. Social support correlated to teacher's performance with the correlation value is -.181 and self-efficacy correlated to teacher's performance with correlation value of .196. Social support has a negative effect on the teacher's performance, so it's mean that if social support increase, then teacher's performance would decrease. The vector was different for selfefficacy, which is in a positive value. So, when self-efficacy increased then teacher's performance would increase too. This research concluded that social support and self-efficacy have a correlation on PAUD teacher's performance. Furthermore, in an effort to achieve optimal performances among inclusive PAUD teachers in Bali, the aspect of selfefficacy is needed to involve in the personal development program.
\end{abstract}

Keywords: Teaching Performance, Work Engagement, Psychological Competence of Teacher, Teaching Evaluation, Early Childhood Education

\section{INTRODUCTION}

Education for All (EFA) is launched by the United Nations Educational, Scientific and Cultural Organization (UNESCO), as a reference for educational opportunities for all children in the world. It is adapted from the 2000 Education Forum in Dakar, which is started with the World Declaration on Education for All and the Framework for Action to Meet Basic Learning Needs was held in Jomtien, Thailand in 1990 and the World Conference on Children with Special Needs was held in 1994 in Salamanca, Spain [1]. Through that forum, the needs for education concept for children with disabilities was emphasized again. The fulfilling of basic educational needs are also outlined in the Millennium Development Goals (MDGs). The MDGs are eight goals with measurable targets and clear deadlines for improving the lives of the world's poorest people. To meet these goals, the governments of 189 countries was signed this declaration. The Indonesian government is one country that is committed to this issue. In line with the progress of the EFA, Indonesia formally declared an inclusive education program, on August 11, 2004, in Bandung. The program is thought to be able to answer the basic needs of education for children with special needs (there are approximately around 1.6 million, based on the 2017 Indonesian Statistical Bureau) in Indonesia,

The UNESCO evaluated 15 years of EFA implementation around the world in 2015. Based on the report, UNESCO is claimed that there is a positive trend in increasing education equity in the world. However, there were several notes, especially for the active participation and involvement of various parties. The report has also suggested an evaluation of the program from various sides [2], [3]. The evaluation of educational programs includes four aspects, namely context, input, process, and product [4]. Based on these aspects, the role of the teacher as a designer, facilitator and evaluator of the inclusion program in each class needs to be considered. 
Previous research on inclusive education in Indonesia found that the ineffective management of inclusive classes [5]. That study is examined the inadequate knowledge and skills of inclusive teachers so that their performance in the management of inclusive classrooms is not optimum. Other research was conducted by Lili Novitayanti and Luh Ayu Tirtayani is describes ineffective interactions between teachers and students [6]. The attitudes and skills of teachers in implementing learning and evaluation are known as weak. However, from the aspect of earning design, the teacher's performance shown is adequate. Teachers are played a role in the sustainability of the program. The need for adequate skills of teachers to conduct inclusive education programs is needed [7]. Therefore, the teacher's performance to manage the inclusive class needs to be a concern.

Performance appraisal is the process of evaluating employees' abilities in duties and responsibilities [8]. Performance is an expression of knowledge, skills, values, and attitudes, both in quality and quantity, as part of their responsibilities [9][10][11]. The part of teacher's responsibility includes four aspects, that is pedagogic, personality, social, and professional (Indonesian Law No. 20/2003 on the national education system; Indonesian Law No. 14/2005 on teachers and lecturers: Indonesian Government Rules No. 19/2005 on national educational standards). Teacher performance is an expression of knowledge, values, attitudes, and skills that are manifested in the appearance, actions, and work performance of the teacher as well as their responsibilities in the pedagogic, personality, social, and professional fields. Practically, teacher performance can be seen from the activities of planning, implementing, and assessing the teaching and learning process, based on the work ethic, professionalism, and discipline.

The assessment of the inclusive teacher's performance is a part of the monitoring of the implementation of the inclusion program itself. The background of this study based on the ineffective inclusive early childhood teachers' performance. Studies on social and psychological aspects are important to determine the relationship between performance and other variables. Two of these aspects that can be studied are social support and self-efficacy. Social support is defined as the provision of physical, emotional, informational, and instrumental assistance that an individual perceives from his or her social networks [12], [13]. Social support is the action of help or support that individuals receive from certain people in their lives and are in a certain social environment that makes recipients feel cared for [14]. Social support consists of several components, including emotional support, appreciation, instrumental, and informative [15]. Positive social support has an increasing impact on teacher work performance, and vice versa [16]. Therefore, attention to social support, in this case for PAUD educators, needs to be increased, so that teachers feel given attention.

According to Albert Bandura, self-efficacy is a judgment of capability [17]. As a judgment, self-efficacy is a dialogue between a person's personal thoughts on their personal abilities and the workload they receive [17]. Low self-efficacy leads individuals to assess negative conditions and believe that they are unable to perform well, and vice versa. Self-efficacy affects the way individuals think, feel, and motivate themselves to act. Self-efficacy has become an important framework to predict and explain judgments that influence teachers' decisions and actions. Mark Wyatt defines teacher efficacy as' Teachers' beliefs in their capabilities of supporting learning in various tasks and context-specific, cognitive, metacognitive, affective, and social ways' [18]. Teacher self-efficacy is related to the work performed as educators, as well as teaching and other related tasks [19]-[21]. In the teacher's role of educator, especially in the inclusive class, self-efficacy is seen in the teacher's belief in being able to organize and achieve optimal results from learning and evaluation activities carried out in the inclusive class.

According to the background of the study, selfefficacy in relation to teacher performance has been a lot to study, however, no one has investigated teacher performance in the setting of inclusive early childhood education. As well as the research on the direct correlation between social support and teacher performance is also not conducting yet. Therefore, this study aims to determine the level of connection between social support and self-efficacy on the performance of inclusive PAUD teachers in Bali.

\section{METHODS}

This research was conducted in Bali by involving PAUD institutions. The population of this study were teachers from early childhood education institutions who were carrying out a pilot project (piloting project) for inclusive early childhood education. There are about 170 inclusive PAUD teachers who are willing to be involved in this research.

This study is a correlation study to determine the level of the relationship between social support and selfefficacy on the performance of inclusive PAUD teachers. Teacher performance is defined as the appearance of the teacher in planning, implementing, and assessing the teaching and learning process based on the work ethic and professional discipline of the teacher. Social support is defined as assistance provided by certain people in the school environment or organizational groups, with the hope of making teachers feel cared for and loved. Selfefficacy is defined as the teacher's belief in his ability to organize and organize learning, specifically in inclusive 
classes, as an effort to fulfil professional duties as a teacher.

The data in this study were collected using a questionnaire with a choice of answers on a Likert scale. There are three parts of the questionnaire given, according to the variables being measured. The research instrument has been declared valid by judges and has high reliability $(0.79-0.80)$. Data analysis begins with the prerequisite test using the Chi-Square Technique $\left(\chi^{2}\right)$ and the linearity test is seen at the significance value of Deviation from linearity. In the final stage, the hypothesis is tested using the product-moment correlation technique. The correlation coefficient is a measure used to describe the degree of relationship between variables [22]. The correlation coefficient value is in the range $-1<0<1$. A positive coefficient value shows a linear relationship, while a negative coefficient value shows a relationship that is in the opposite.

\section{FINDINGS AND DISCUSSION}

Data descriptions of social support, self-efficacy, and teacher performance are presented in Table 1, which respectively contains the mean, standard deviation, and variance.

Table 1. Descriptive data of social support, self-efficacy, and teacher performance

\begin{tabular}{|l|c|c|c|}
\hline \multicolumn{1}{|c|}{ Variables } & $\begin{array}{c}\text { Mean } \\
(\boldsymbol{M})\end{array}$ & $\begin{array}{c}\text { Deviation } \\
\text { standards } \\
(\mathbf{S D})\end{array}$ & $\begin{array}{c}\text { Varian } \\
\left(\mathbf{S}^{2}\right)\end{array}$ \\
\hline Social support & 56.54 & 3.87 & 19.98 \\
\hline Self-efficacy & 33.42 & 3.03 & 9.19 \\
\hline $\begin{array}{l}\text { Teacher } \\
\text { performances }\end{array}$ & 45.68 & 3.86 & 14.91 \\
\hline
\end{tabular}

According to the data exposure in Table 1, the social support variable has a mean of 56.54 with a standard deviation of 3.87. The social support data variant is 19.98. Self-efficacy as the second variable has a mean of 33.42 and a standard deviation of 3.03 and a variant of 9.19. The teacher performance variable has a mean of 45.68 with a standard deviation of 3.86 and a variant of 14.91. All variables have a standard deviation value that is lower than the mean, so it can be said that this data has a good representation value.

Furthermore, the normality test was carried out using the Chi-Square Technique $\left(\chi^{2}\right)$ and linearity using the Deviation from linearity significance value. Social support variables $\left(\chi_{\text {test }}^{2}\right)$, self-efficacy $\left(\chi_{\text {test }}^{2}\right.$, and teacher performance $\left(\chi^{2}\right.$ test $)$, s, with sig. $<5 \%$ and degree of freedom $(\mathrm{df})=5$, have the calculation result $\chi), \chi_{\text {test }}^{2}<$

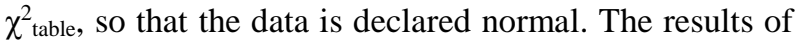
other prerequisite tests with a significance value of deviation from linearity on the social support (.50) and self-efficacy (.98) variables are greater than .05 , so the relationship between the two variables to teacher performance is linear.

Further analysis is on the hypothesis of the relationship between social support and self-efficacy with teacher performance (Table 2).

Table 2. Correlation coefficient analysis

\begin{tabular}{|l|r|r|r|r|r|}
\hline \multicolumn{7}{|c|}{ Model } & \multicolumn{7}{|c|}{$\begin{array}{l}\text { Unstandardize } \\
\text { d Coefficients }\end{array}$} & $\begin{array}{l}\text { Stan. } \\
\text { Coeffi } \\
\text { cients }\end{array}$ & \multirow{2}{*}{ t } & \multirow{2}{*}{ Sig. } \\
\cline { 2 - 5 } & $\mathrm{B}$ & $\begin{array}{l}\text { Std. } \\
\text { Error }\end{array}$ & Beta & & \\
\hline (Constant) & 32,137 & 5,606 & & 5,733 &, 000 \\
\hline $\begin{array}{l}\text { Self- } \\
\text { efficacy }\end{array}$ &, 196 &, 093 &, 194 & 2,094 &, 038 \\
\hline $\begin{array}{l}\text { Social } \\
\text { Support }\end{array}$ &,- 181 &, 088 &,- 180 & - &, 042 \\
\hline a. Dependent Variable: Teacher Performance & 2,044 & \\
\hline
\end{tabular}

The product moment correlation test on the social support variable for teacher performance shows the correlation coefficient $r=-.181$, while the $r_{\text {table }}$ value $(\alpha$ $<.05)=.148$. These results indicate that there is a significant correlation between social support and teacher performance. The correlation value of social support for teacher performance with a negative value means that the correlation is not unidirectional. Furthermore, the product moment correlation test on the self-efficacy variable towards teacher performance shows the calculated correlation coefficient $r=.196$. The value of $r_{\text {table }}(\alpha<.05)=.148$. So, these results indicate that there is a significant relationship between self-efficacy and teacher performance.

Based on the test, social support and self-efficacy have a significant relationship with teacher performance. Even though there is a significant relationship, the interpretation of the correlation coefficient value shows that this relationship is very weak, namely in the range $>0-.25$ [23]. This means that the strength of social support and selfefficacy in explaining teacher performance is classified as very weak.

The finding that self-efficacy has a significant relationship to teacher performance further supports existing theories. Nikki Bray-Clark and Reid Bates explains that self-efficacy has a contribution to teacher effectiveness in teaching [24]. Self-efficacy is one of the factors that support teacher professionalism. Besides the direct increase in performance, self-efficacy also correlates with teacher motivation and work climate [25]. The existence of a positive belief in one's ability as an educator encourages teachers to improve their professional skills. It is important for teachers to feel and believe in their competence in learning. One of the professional skills affected by self-efficacy is the ability of the teacher to give instructions or organize learning [26], [27]. Apart from organizing learning, self-efficacy also affects the teacher's relationship among their peers' groups. Good self-efficacy 
will have a positive impact on teacher-colleague relationships. This self-efficacy can be increased through participation in self-development programs [28]. Participation in self-development programs will provide opportunities for teachers to identify their potential and needs so that later they will be able to have confidence in what they are. Though increasing teacher self-efficacy needs attention, and one of the recommended ways is to design self-development programs for teachers. Stimulation through teacher development programs will be able to increase the self-efficacy of educators and later improve teacher performance and professionalism.

A significant performance proves that the environment plays a role in work performance. Social support is defined as information leading the subject to believe that he/she is cared for and loved, esteemed, and a member of a network of mutual obligations [12]. Social support can take various forms, such as: aiding in lesson planning, solutions to student problems, and even being a listener for teacher complaints [29], [30]. Social support can help teachers to cope with emotional conditions. Coping with the appropriate teacher will affect their involvement in learning management [31].

An interesting result of this study is the correlation of social support toward teacher performance is non-linear. Previous studies have supported a linear correlation of social support with teacher performance. Social support can generally make individuals feel cared for, cherished and loved. In this context, the social environment supports the teacher to be able to solve the problems at hand. With the solution and efforts to solve the problem, then the teacher can then return to activities according to their role. In this study, the existence of a non-linear relationship shows that the higher the social support, the lower the teacher performance. Negative correlation can be related to variables that are not used as controls, including: comfort with social support and the type of attachment.

Comfortability is an important factor for the acceptance of social support [32]. If someone is comfortable with this form of social support, the learning duty will be reduced and individual functioning will increase. On the contrary, if the discomfort is high, social support will increase the stress and make the performance decrease. The second factor is the type of attachment. Anxious and avoidant attachment types tend to seek less support, even though they are faced with stressful conditions [33]. This may explain that even though there is high social support, teachers with anxious or avoidant attachment types tend not to use these social support resources in solving the problems they face, so that teacher work performance is not positively influenced. This assumption is certainly not straightforwardly accepted, and further research is needed.

\section{CONCLUSION}

This study concluded that social support and self-efficacy has a significant impact on inclusive PAUD teachers' performances. Social support shows a negative correlation, so it's mean that if social support increase, then the teacher's performance would decrease. The vector was different for self-efficacy. Self-efficacy has a positive effect on the teacher's performance, so when self-efficacy increased then the teacher's performance would increase too. Furthermore, to achieve optimum performances among inclusive PAUD teachers in Bali, the aspect of self-efficacy is needed to involve in the personal development program.

\section{AUTHORS' CONTRIBUTIONS}

LAT designed and performed research, analyzed data, and co-wrote the paper. NMA performed research, analyzed data, and co-wrote the paper.

\section{ACKNOWLEDGMENTS}

The authors would like to express their gratitude to the Institution of Research and Community Service (LPPM) Universitas Pendidikan Ganesha for its support through Penelitian Dasar 2020, with the research contract No. $624 / \mathrm{UN} 48.16 / \mathrm{LT} / 2020$. The authors also would like to express thanks to the participant who took part in this study, and various organizations that have helped while this research conducted.

\section{REFERENCES}

[1] UNESCO, The Salamanca Statement and Framework for Action on Special Needs Education. Salamanca: UNESCO, 1994.

[2] M. Ainscow and S. Miles, Making education for all inclusive: where next?, Prospects, vol. 38, no. 1, Mar. 2008, pp. 15-34.

[3] M. Ainscow, R. Slee, and M. Best, Editorial: the Salamanca Statement: 25 years on, Int. J. Incl. Educ., vol. 23, no. 7-8, Aug. 2019, pp. 671-676.

[4] D. L. Stufflebeam, The CIPP Model for Evaluation, in International Handbook of Educational Evaluation, D. L. Stufflebeam and T. Kellaghan, Eds. Dordrecht: Springer Netherlands, 2003, pp. 31-62.

[5] E. Purnomo, Kebutuhan Guru Sekolah Dasar Inklusi dalam Meningkatkan Kompetensi Melalui Media Video, Kwangsan, vol. 4, no. 2, 2016, pp. 95-109.

[6] L. Novitayanti and L. A. Tirtayani, 'TeachersStudents' Interaction in Early Childhood Inclusion Program', J. Educ. Res. Eval., vol. 3, no. 2, Aug. 2019, pp. 96. 
[7] S. Aziz, M. Mahmood, and Z. Rehman, 'Implementation of CIPP Model for Quality Evaluation at School Level: A Case Study', J. Educ. Educ. Dev., vol. 5, no. 1, May 2018, pp. 189.

[8] N. A. Saleemi, Personnel management simplified, Nairobi: ACME Press, 2011.

[9] H. B. Uno and N. Lamatenggo, Teori Kinerja dan Pengukurannya, Jakarta: Bumi Aksara, 2014.

[10] H. E. Mulyasa, Uji Kompetensi dan Penilaian Kinerja Guru, Bandung: PT Remaja Rosdakarya, 2017.

[11] R. Ahmadi, Profesi Keguruan, Yogyakarta: ArRuzz Media, 2018.

[12] S. Cobb, Social Support as a Moderator of Life Stress, Psychosom. Med., vol. 38, no. 5, Sep. 1976, pp. 300-314.

[13] M. Lu et al., Self-esteem, social support, and life satisfaction in Chinese parents of children with autism spectrum disorder, Res. Autism Spectr. Disord., vol. 17, Sep. 2015, pp. 70-77.

[14] R. Tumanggor, R. Kholis, and Nurrochim, Ilmu sosial dan budaya dasar, Jakarta: Kencana Prenadamedia Group, 2017.

[15] Nursalam and D. K. Ninuk, Asuhan Keperawatan pada pasien terinfeksi HIV AIDS, Jakarta: Salemba Medika, 2007.

[16] M.-S. Chung, Teacher Efficacy, Collective SelfEsteem, and Organizational Commitment of Childcare Teachers: A Moderated Mediation Model of Social Support, Front. Psychol., vol. 10, May 2019.

[17] A. Bandura, The evolution of social cognitive theory, in Great minds in management, Oxford: Oxford university press, 2005, pp. 9-35.

[18] M. Wyatt, Towards a re-conceptualization of teachers' self-efficacy beliefs: tackling enduring problems with the quantitative research and moving on, Int. J. Res. Method Educ., vol. 37, no. 2, Apr. 2014, pp. 166-189.

[19] M. Zee and H. M. Y. Koomen, 'Teacher selfefficacy and its effects on classroom processes, student scademic adjustment, and teacher wellbeing', Rev. Educ. Res., vol. 86, no. 4, Dec. 2016, pp. 981-1015.

[20] M. Cocca, A. Cocca, E. A. Martínez, and M. G. R. Bulnes, Correlation between self-efficacy perception and teaching performance: The case of Mexican preschool and primary school teachers', Arab World English J., vol. 9, no. 1, 2018, pp. 5670 .
[21] S. K. Khanshan and M. H. Yousefi, The relationship between self-efficacy and instructional practice of in-service soft disciplines, hard disciplines and EFL teachers, Asian-Pacific J. Second Foreign Lang. Educ., vol. 5, no. 1, Dec. 2020, p. 1.

[22] S. Siregar, Statistik Parametrik untuk Penelitian Kuantitatif, Jakarta: Bumi Aksara, 2013.

[23] J. Sarwono, Metode penelitian kuantitatif dan kualitatif, Yogyakarta: Graha Ilmu, 2006.

[24] N. Bray-Clark and R. Bates, Self-Efficacy Beliefs and Teacher Effectiveness: Implications for Professional Development, Prof. Educ., vol. 26, no. 1, 2003, pp. 13-22.

[25] D. Barni, F. Danioni, and P. Benevene, Teachers' Self-Efficacy: The Role of Personal Values and Motivations for Teaching, Front. Psychol., vol. 10, Jul. 2019, pp. 1-7.

[26] F. Pajares, Current directions in self-efficacy research, in International advances in self research, 32nd ed., H. W. Marsh, R. G. Craven, and D. M. McInerney, Eds. Information Age Publishing, 1997.

[27] H. Withy, Strategies for developing and maintaining self-efficacy in teachers, The Education Hub, 2019.

[28] H. Yang, The effects of professional development experience on teacher self-efficacy: analysis of an international dataset using Bayesian multilevel models, Prof. Dev. Educ., vol. 46, no. 5, Oct. 2020, pp. 797-811.

[29] L. Minghui, H. Lei, C. Xiaomeng, and M. Potměšilc, Teacher Efficacy, Work Engagement, and Social Support Among Chinese Special Education School Teachers, Front. Psychol., vol. 9, May 2018

[30] C. Bounds, Moderating Effects of Social Support on the Association Between Teacher-Directed Violence and Stress, Eastern Illinois University, 2017.

[31] D. Hultell and J. P. Gustavsson, Factors affecting burnout and work engagement in teachers when entering employment, Work, vol. 40, no. 1, 2011, pp. 85-98.

[32] K. Kaniasty and F. H. Norris, Help-Seeking Comfort and Receiving Social Support: The Role of Ethnicity and Context of Need, Am. J. Community Psychol., vol. 28, no. 4, Aug. 2000, pp. 545-581.

[33] A. Dujardin et al., Middle childhood supportseeking behavior during stress: Links with selfreported attachment and future depressive symptoms, Child Dev., vol. 87, no. 1, 2016, pp. 326-340. 